PART III. OTHER

DZIAŁ III. RÓŻNE

\title{
OCCURRENCE OF CANDIDA SPP. IN HEALTHY ORAL MICROBIOTA
}

\section{WYSTĘPOWANIE CANDIDA SPP. W MIKROBIOCIE JAMY USTNEJ W WARUNKACH ZDROWIA}

\author{
Łukasz Kimsa $^{1(B, C, F)}$, Małgorzata Tokarska-Rodak ${ }^{1(A, B, C, D, E)}$
}

${ }^{1}$ Department of Public Health, Faculty of Health Sciences, Pope John Paul II State School of Higher Education in Biala Podlaska, Poland

Authors' contribution Wkład autorów: A. Study design/planning zaplanowanie badań B. Data collection/entry zebranie danych C. Data analysis/statistics dane - analiza i statystyki D. Data interpretation interpretacja danych E. Preparation of manuscript przygotowanie artykułu F. Literature analysis/search wyszukiwanie i analiza literatury G. Funds collection zebranie funduszy
Tables: 4

Figures: 0

References: 31

Submitted: 2020 Feb 20

Accepted: 2020 March 30

\section{Summary}

Background. Candida is a strain of fungi that is found on the surface of healthy mucous membranes of the oral cavity. Yet, Candida may also be considered opportunistic microorganisms. The pathogenicity of Candida spp. depends on strain-specific characteristics including, invasiveness, adhesion, and production of biofilm abilities as well as the production of enzymes allowing the colonization of tissue. The aim of the paper was to evaluate the frequency of Candida spp. occurrence in the oral microbiota of healthy adults, and its relation with risk factors and colonization. Material and methods. This study consisted of 72 healthy participants (from the Lubelskie Voivodeship between 19 and 73 years of age). Medical history was collected to determine potential relationships to risk factors affecting oral microbiota (past oral cavity diseases, chronic diseases, and smoking). The participants who were qualified had no oral cavity infections during the study. The collected clinical samples (oral cavity swabs) were disseminated on the chromogenic base for isolation and differentiation of Candida spp. Results. The frequency of Candida spp. occurrence was at the level of $63.8 \%$. C. albicans was the most frequently identified species (56.5\%). C. glabrata $(45.6 \%)$ and C. tropicalis $(23.9 \%)$ were identified less often. In $21.7 \%$ of swabs, two species of Candida were identified and in $2.2 \%$ of swabs three species identified. The most common colonization risk factor was associated with smoking (32.6\%). Conclusions. Yeasts of Candida species are part of the healthy microflora of the oral cavity in people of different ages and may occur as single species or coexist with other species. The coexistence of chronic diseases, propensity for oral cavity infections and smoking significantly influence the Candida colonization. This may result in future clinical consequences, for example in cases of immunodepression.

Keywords: Candida, Candida albicans, Candida tropicalis, Candida glabrata, oral cavity, microbiota

\section{Streszczenie}

Wprowadzenie. Grzyby z rodzaju Candida mogą w warunkach fizjologicznych występować na powierzchni błony śluzowej jamy ustnej, jednak równocześnie uznawane są za drobnoustroje oportunistyczne. Chorobotwórczość Candida spp. zależy od właściwości szczepu, inwazyjności, zdolności do adhezji i tworzenia biofilmu oraz wytwarzania enzymów umożliwiających kolonizację tkanek. Celem pracy była ocena częstości występowania Candida spp. w mikrobiocie jamy ustnej u osób dorosłych $\mathrm{w}$ warunkach zdrowia oraz określenie związku pomiędzy czynnikami ryzyka a kolonizacją. Materiał i metody. Grupę badaną stanowiły 72 zdrowe osoby (mieszkańcy województwa lubelskiego, w wieku od 18 do 73 lat), od których zebrano wywiad odnośnie obecności czynników wpływających na stan mikrobioty jamy ustnej (występowania w przeszłości chorób jamy ustnej, istnienia chorób przewlekłych oraz palenia papierosów). Do udziału w badaniach zakwalifikowano osoby, które w trakcie ich prowadzenia zadeklarowały brak infekcji w obrębie jamy ustnej. Pobrany materiał kliniczny (wymazy z jamy ustnej) posiano na podłoże chromogenne do izolacji i różnicowania Candida spp. Wyniki. Częstość występowania Candida spp. odnotowano na poziomie 63,8\%. Najczęściej identyfikowano C. albicans $(56,5 \%)$, rzadziej C. glabrata $(45,6 \%)$ i $C$. tropicalis $(23,9 \%)$. W $21,7 \%$ wymazów rozpoznano po dwa gatunki Candida, a w 2,2\% wymazów trzy. Najczęstszym deklarowanym czynnikiem ryzyka kolonizacji było palenie tytoniu $(32,6 \%)$. Wnioski. Drożdżaki z rodzaju Candida są obecne $\mathrm{w}$ mikroflorze jamy ustnej $\mathrm{w}$ warunkach zdrowia u osób $\mathrm{w}$ różnym wieku i mogą występować jako pojedyncze gatunki lub współistnieć obok siebie w różnych konfiguracjach. Współistnienie chorób przewlekłych, skłonności do infekcji w obrębie jamy ustnej oraz palenie papierosów wpływają istotnie na kolonizację jamy ustnej drożdżakami, co może w przyszłości skutkować konsekwencjami klinicznymi w przypadku spadku odporności.

Słowa kluczowe: Candida, Candida albicans, Candida tropicalis, Candida glabrata, jama ustna, mikrobiom

Kimsa Ł, Tokarska-Rodak M. Occurrence of Candida spp. in healthy oral microbiota. Health Prob Civil. 2020; 14(2): 124-130.

https://doi.org/10.5114/hpc.2020.94132

Address for correspondence / Adres korespondencyjny: Małgorzata Tokarska-Rodak, Department of Public Health, Faculty of Health Sciences, Pope John Paul II State School of Higher Education, Sidorska 95/97, 21-500 Biała Podlaska, Poland, e-mail: rodak.malgorzata@gmail.com, phone: +48 83 344 99 00 ORCID: Małgorzata Tokarska-Rodak https://orcid.org/0000-0003-2297-970X

Copyright: (C) Pope John Paul II State School of Higher Education in Biała Podlaska, Łukasz Kimsa, Małgorzata Tokarska-Rodak. This is an Open Access journal, all articles are distributed under the terms of the Creative Commons Attribution-NonCommercial-ShareAlike 4.0 International (CC BY-NC-SA 4.0) License (http:// creativecommons.org/licenses/by-nc-sa/4.0/), allowing third parties to copy and redistribute the material in any medium or format and to remix, transform, and build upon the material, provided the original work is properly cited and states its license. 


\section{Introduction}

In a healthy physiological state, the mucous membrane of the oral cavity creates a suitable environment for the collonization of many microorganisms, including Candida spp. yeasts. The ability to colonize tissue and the nature of infections caused by yeasts depends on the strain-specific features including invasiveness, adhesion and biofilm creation abilities, enzymatic activity and the immune status of the host [1-6]. Candida albicans is the main pathogenic species and the most frequent cause of candidiasis in humans. It was shown that this species caused proportionally more exogenous and endogenous infections (50-70\%) and is the most frequent microorganism isolated from other yeast-like fungi in oral cavity candidiasis [2, 7]. Candida glabrata is the second most frequently obtained isolate from the mucous membrane of the oral cavity. It can occur independently or coexist with $C$. albicans. Candida parapsilosis and $C$. tropicalis are different species of yeast. They can also be isolated and proliferate in particularly in cancer patients with generalized infection [8, 9]. C. krusei, C. guilliermondi, C. famata, C. pseudotropikalis, and $C$. dubliniensis are less common species but can also cause human infections [1, 2]. Candida albicans, as an opportunistic microorganism, may be a cause of superficial as well as systemic candidasis, especially in patients with immunological disorders [3]. Steroid treatment, invasive medical procedures, skin injuries resulting from burns, diabetes, low birth weight and infection e.g. HIV are factors influencing the development of candidasis $[10,11]$. Local factors facilitating infections within the oral cavity include the usage of acrylic dentures, radiotherapy and anticancer medication and the resulting alteration of the oral cavity epithelium, salivary secretion disorders as well as its quantitative and qualitative alterations, bad oral hygiene, smoking, and alcohol consumption [12].

The first phase of tissue colonization and invasion of microorganisms is the phenomenon of adhesion [8]. Candida yeasts show the ability to adhere to various types of epithelial and endothelial cells, blood platelets, lymphocytes, leukocytes as well as biopolymers. C. albicans, in particular, adheres to the protein receptors of the salivary proteins, extracellular matrix and serum proteins [13]. The main adhesive proteins of Candida spp. are mannoproteins as well as Als (agglutinin-like sequence) Hwp (hyphal wall protein), Eap (enhanced adherence to polystyrene) $[8,12,14]$. Mannoproteins constitute around $15.2-22.9 \%$ of dry weight of cell wall of yeasts [10]. Enzymatic activity is the virulent trait that allows survival in the organism of the host. The ability of Candida spp. to produce enzymes facilitates invasion into the tissues [4] and secreted aspartic protease causes the degradation of the epithelium constituents, keratin, and collagen. This results in the destruction of proteins participating in the immunological response $[8,15]$. This leads to epithelial damagein the invaded area and allows the pathogen to penetrate. Candida spp. produces acidic proteases that protect it from phagocytosis by the host's inflammatory cells which are significant in the first phase of the infection $[8,15]$.

The aim of the paper was to evaluate the frequency of Candida spp. occurrence in the microbiota of the oral cavity in healthy adults as well as establish the relationship between risk factors and colonization.

\section{Material and methods}

The study group consisted of 72 participants (59 women and 13 men), inhabitants of Lubelskie Voivodeship, Poland, in ages between 18 and 73 (average age amounted at 30, SD 14.2). Medical history concerning occurrence of oral diseases in the past, stabilized chronic diseases and smoking (classic cigarettes and electronic cigarettes) was collected from all participants. People qualified for the research declared no yeast infections in the oral cavity during the study. Swabs collected in the laboratory conditions from the interior cheek and palate surface constituted the clinical material. Swabs were collected once. The collected material was disseminated in the chromogenic microbiological bases for isolation and differentiation of species of Candida yeast (BIOMAXIMA; differentiation of $C$. albicans, C. tropicalis, C. krusei, C. glabrata). The cultures have been incubated in aerobic conditions in the temperature of $37^{\circ} \mathrm{C} \pm 1^{\circ} \mathrm{C}$ for 48 hours. The results and reading of the breeding were interpreted according to the base producer's guidelines: green colonies - C. albicans, blue colonies - C. tropicalis, pink-purple, shiny colonies - C. glabrata and matte, flossy, pink colonies - C. krusei. The consent for the study was obtained from the Bioethics Committee at Pope John Paul II State School of Higher Education in Biała Podlaska, Poland (no 9/2018). The collected data were statistically analyzed utilizing the Statistica v.10 software (Pearson's chisquare test, U Mann-Whitney's). The significance level in all analyzed cases was assumed at $\mathrm{p}<0.05$. 


\section{Results}

The analysis of the mycological research

Out of 72 study participants, 46 patients (63.8\%) tested positive for the colonization of Candida spp. yeast. The occurrence of only one species was reported in $76.1 \%$ of the positive samples (35 swabs): C. albicans (n=17; $36.9 \%)$, C. glabrata $(\mathrm{n}=13 ; 28.3 \%)$, C. tropicalis $(\mathrm{n}=5 ; 10.9 \%)$. The growth of $C$. krusei was not observed.

The growth of two species of Candida spp. was reported in 10 positive cultures (21.7\%) C. albicans and $C$. glabrata $-10.9 \%$ (5 swabs), C. albicans and C. tropicalis - 6.5\% (3 swabs), C. glabrata and C. tropicalis $-4.3 \%$ (2 swabs).

The growth of three Candida spp. species (C. albicans, C. glabrata, C. tropicalis) was observed in material from 1 patient.

C. albicans was reported in a total of 26 swabs (56.5\%), C. glabrata in 21 swabs (46.6\%) and C. tropicalis in 11 swabs $(23.9 \%)$

There was no significant dependence between the occurrence of certain Candida species and gender or age of the studied group. Details of the mycological results are presented in Table 1 and Table 2.

Table 1. The results of breeding toward Candida spp. in swabs from oral cavities of healthy people

\begin{tabular}{|c|c|c|c|c|c|}
\hline \multirow{2}{*}{$\begin{array}{l}\text { The results of } \\
\text { breeding }\end{array}$} & \multirow{2}{*}{$\begin{array}{c}\text { Swabs } \\
\text { N(\%) }\end{array}$} & \multirow{2}{*}{ C. albicans } & \multirow{2}{*}{ C. glabrata } & \multirow{2}{*}{ C. tropicalis } & Swabs \\
\hline & & & & & $N(\%)$ \\
\hline \multirow{7}{*}{ Positive } & \multirow{7}{*}{$46(64)$} & + & - & - & $17(36.9)$ \\
\hline & & - & + & - & $13(28.3)$ \\
\hline & & - & - & + & $5(10.9)$ \\
\hline & & + & + & - & $5(10.9)$ \\
\hline & & + & - & + & $3(6.5)$ \\
\hline & & - & + & + & $2(4.3)$ \\
\hline & & + & + & + & $1(2.2)$ \\
\hline Negative & $26(36)$ & & & & \\
\hline
\end{tabular}

Table 2. Candida spp. species noted in cultures from oral cavity - classification according to the age of study participants

\begin{tabular}{|c|c|c|c|c|c|}
\hline Age & \multicolumn{2}{|c|}{$\begin{array}{c}\text { Studied group } \\
\text { N(\%) }\end{array}$} & C. albicans & C. tropicalis & C. glabrata \\
\hline \multirow{5}{*}{$18-30$} & \multirow{5}{*}{$27(58.7 \%)$} & 9 & $\mathrm{x}$ & - & - \\
\hline & & 4 & - & $\mathrm{x}$ & - \\
\hline & & 8 & - & - & $x$ \\
\hline & & 2 & $\mathrm{x}$ & $\mathrm{x}$ & - \\
\hline & & 4 & $\mathrm{x}$ & - & $\mathrm{x}$ \\
\hline \multirow{4}{*}{$31-40$} & \multirow{4}{*}{$8(17.4 \%)$} & 3 & $\mathrm{x}$ & - & - \\
\hline & & 3 & - & - & $\mathrm{x}$ \\
\hline & & 1 & $\mathrm{x}$ & $\mathrm{x}$ & \\
\hline & & 1 & - & $\mathrm{x}$ & $\mathrm{x}$ \\
\hline \multirow{4}{*}{$41-50$} & \multirow{4}{*}{$4(8.7 \%)$} & 1 & $\mathrm{x}$ & - & - \\
\hline & & 1 & - & $\mathrm{x}$ & - \\
\hline & & 1 & - & - & $\mathrm{x}$ \\
\hline & & 1 & $\mathrm{x}$ & - & $\mathrm{x}$ \\
\hline \multirow{4}{*}{$>50$} & \multirow{4}{*}{$7(15.2 \%)$} & 4 & $\mathrm{x}$ & - & - \\
\hline & & 1 & & - & $\mathrm{x}$ \\
\hline & & 1 & - & $\mathrm{x}$ & $\mathrm{x}$ \\
\hline & & 1 & $\mathrm{x}$ & $\mathrm{x}$ & $\mathrm{x}$ \\
\hline Total & \multicolumn{2}{|c|}{46} & $26(36.1 \%)$ & $11(15.3 \%)$ & $21(29.2 \%)$ \\
\hline
\end{tabular}


The analysis of the physical examination

Participants were also asked about past oral cavity ailments such as dental caries, gum diseases, mucosal inflammation, and others. Sixteen people $(16 / 72,22 \%)$ reported the occurrence of one or multiple of the abovementioned ailments (Table 3). Out of them, in eleven people $(11 / 16,69 \%)$ the growth of different yeast species was observed. C. albicans was reported most often ( $\mathrm{p}=0.01)$. Seven out of eleven people $(63.6 \%)$ informed about caries lesions in teeth. C. albicans were present in the cultures of four of them. In two cases $C$. albicans and $C$. tropicalis coexisted while in one case the coexistence of C. albicans, C. glabrata, and C. tropicalis was reported. The detained data was presented in Table 3.

Table 3. The occurrence of Candida spp. species depending on the declared oral cavity diseases

\begin{tabular}{|c|c|c|c|c|c|}
\hline $\begin{array}{l}\text { Oral cavity } \\
\text { diseases }\end{array}$ & \multicolumn{2}{|c|}{$\begin{array}{c}\text { Number of people } \\
(\mathrm{N})\end{array}$} & C. albicans & C. tropicalis & C. glabrata \\
\hline \multirow{5}{*}{ Dental caries } & \multirow{5}{*}{8} & 4 & $\mathrm{x}$ & - & - \\
\hline & & 1 & - & $\mathrm{x}$ & - \\
\hline & & 1 & - & - & $\mathrm{x}$ \\
\hline & & 1 & $\mathrm{x}$ & - & $\mathrm{x}$ \\
\hline & & 1 & $\mathrm{x}$ & $\mathrm{x}$ & $\mathrm{x}$ \\
\hline \multirow{2}{*}{ Gum diseases } & \multirow{2}{*}{3} & 1 & $\mathrm{x}$ & $\mathrm{x}$ & - \\
\hline & & 2 & $\mathrm{x}$ & - & $\mathrm{x}$ \\
\hline $\begin{array}{c}\text { Dental caries/gum } \\
\text { diseases }\end{array}$ & \multicolumn{2}{|c|}{5} & - & - & - \\
\hline Total & \multicolumn{2}{|c|}{16} & $9(56.2 \%)$ & $3(18.7 \%)$ & $5(31.2 \%)$ \\
\hline
\end{tabular}

Self-reports by the participants revealed 59 participants (81.9\%) did not have any stabilized chronic diseases, 4 participants (5.6\%) declared cardiovascular diseases, 3 participants (4.1\%) atopic skin diseases and 10 people $(13.9 \%)$ indicated other diseases (endocrinologic, autoimmune, Lyme borreliosis, asthma). The growth of $C$. albicans was reported more often in the smears of people who declared chronic diseases $(\mathrm{p}=0.02)$.

Nineteen participants were smokers (19/72, 26.4\%). Of these 14 smoked standard cigarettes (19.4\%), 3 used electronic cigarettes (4.2\%) and 2 (2.8\%) used both interchangeably. No growth of Candida spp. in smears from oral cavities was observed in 4 out of 19 smokers $(4 / 19,21 \%)$ and in 15 participants $(15 / 19,79 \%)$ growth of Candida spp. yeasts was observed. Eleven participants $(11 / 15,73 \%)$ had growth of single species $C$. albicans, $C$. tropicalis, C. glabrata. In three of these (3/15, 20\%) there was simultaneous growth of two Candida spp. species and in one person $(1 / 15,7 \%)$ who smokes more than 20 cigarettes a day, the growth of three species - C. albicans, C. tropicalis, C. glabrata was observed (Table 4). The growth of $C$. tropicalis was more often noticed in samples gathered from smokers $(\mathrm{p}=0.02)$.

Table 4. The occurrence of Candida spp. species in people smoking regular cigarettes and electronic cigarettes

\begin{tabular}{|c|c|c|c|c|c|}
\hline Smoking & $\begin{array}{l}\text { Number of } \\
\text { cigarettes }\end{array}$ & $\begin{array}{c}\text { Number of } \\
\text { people } \\
\text { (N) }\end{array}$ & C. albicans & C. tropicalis & C. glabrata \\
\hline \multirow{7}{*}{$\begin{array}{c}\text { Regular } \\
\text { cigarettes }\end{array}$} & \multirow{4}{*}{ up to 10} & 4 & $\mathrm{x}$ & - & - \\
\hline & & 2 & - & $\mathrm{x}$ & - \\
\hline & & 1 & - & - & $\mathrm{x}$ \\
\hline & & 1 & $\mathrm{x}$ & - & $\mathrm{x}$ \\
\hline & $11-20$ & 1 & - & $\mathrm{x}$ & - \\
\hline & \multirow{2}{*}{$>20$} & 1 & - & $\mathrm{x}$ & $\mathrm{x}$ \\
\hline & & 1 & $\mathrm{X}$ & $\mathrm{x}$ & $\mathrm{x}$ \\
\hline
\end{tabular}




\begin{tabular}{|c|c|c|c|c|}
\hline \multirow{2}{*}{ Electronic cigarettes } & 1 & $\mathrm{x}$ & - & - \\
\cline { 2 - 5 } & 1 & $\mathrm{x}$ & $\mathrm{x}$ & - \\
\hline $\begin{array}{c}\text { Regular cigarettes and } \\
\text { electronic cigarettes } \\
\text { interchangeably }\end{array}$ & 1 & $\mathrm{x}$ & - & - \\
\cline { 2 - 5 } & 1 & - & $6(40 \%)$ & $5(33 \%)$ \\
\hline Total & 15 & $9(60 \%)$ & & $\mathrm{x}$ \\
\hline
\end{tabular}

\section{Discussion}

It is currently assumed that, in healthy people, oral cavity microbiota may include Candida spp. When exposed to certain predisposing factors this may constitute a danger as Candida spp. participates in the formation of local and generalized mycoses $[2,16,17]$. Candida spp, especially C. albicans as a commensal species may be included in the population colonizing the oral cavity of healthy adults [18]. Initial contact and colonization usually occur in infancy. This study shows that the obtained strains can exist in the microflora for many years. Mild commensal colonization may change pathogenic nature in case of developing immunological disorders or injuries to the mucous membrane. An individual's sensitivity to Candida spp. infections increases with the accessibility of modern treatment methods including antibiotic therapy and solid organs transplantation [19]. The introduction of chemotherapy and radiotherapy to treatment processes may weaken immunological barriers predisposing to fungal infections [20,21]. Candida species are also one of the causes of invasive bloodstream infections [19]. Research carried out by Delaney et al. showed that Candida species present in the oral cavity and constituting the mycobiome influence the bacterial microbiota and the planning of therapeutic interventions should take into consideration the ability of Candida to create biofilms [22].

Previous studies on the incidence of yeast occurrence in the oral cavities of healthy individuals have diverse results. For example, fungi are present in $20-60 \%$ of the population. In children and adolescents, this ratio is twice as high as in adults [23, 24]. Gajdzik-Plutecka et al. report that in oral cavities of healthy children and adolescents the occurrence of Candida spp. is around 45-65\% while in adults at 20-50\% [25]. Singh et al. reported that Candida spp., especially C. albicans, may be present in oral cavities in 30-50\% of healthy adults [18]. In this study, the presence of these fungi was reported to be $64 \%$ of study participants: $58.7 \%$ in people ages $18-30,17.4 \%$ in ages $31-40,8.7 \%$ in ages $41-50$ and $15.2 \%$ in people above 50 years of age. Thus, the result is comparable to the analyses presented by other researchers. Others have shown the presence of Candida to be $59.5 \%$ and $30.7 \%$ of healthy people aged between 20 and 25 years [26]. C. albicans is the fungi species most frequently isolated from the oral cavity. C. glabrata and C. tropicalis appear less often [23]. In this study, the growth of $C$. albicans was found in $56.5 \%$ swabs collected from oral cavities of adults. Other species appeared less often. C. glabrata was observed in $45.6 \%$ of swabs, $C$. tropicalis in $23.9 \%$, and the growth of $C$. krusei was not observed. Single species (C. albicans or C. glabrata or C. tropicalis) appeared in $36.9 \%$ of people, $28.3 \%$ and $10.9 \%$ respectively. Two species of Candida spp. in different configurations were observed in $13.9 \%$ of study participants while three species in $1.4 \%$.

C. albicans and other species like C. parapsilosis, C. glabrata, and C. tropicalis may cause endogenous and exogenous infections. However, $C$. krusei does not occur in healthy physiological flora and can only cause infect exogenously which frequency increases with the application of intravascular cannulation and parenteral feeding [8].

Dental caries, gum, and periodontal diseases are the factors influencing the microbiota of the oral cavity with Candida spp. A significant dependency between the number of teeth with dental caries and the colonization of Candida spp. was reported [26, 27]. In this study, in the majority of study participants (69\%) who reported the above-mentioned ailments, the presence of Candida spp. was observed. Zaremba-Jaworska et al. analyzed patients with prosthetic stomatopathy and reported the occurrence of $C$. albicans in $57.58 \%, C$. tropicalis in $18.18 \%$ and C. glabrata in $14.14 \%$ of cases [28]. Another significant factor predisposing to the colonization of the oral cavity by Candida spp. is smoking. Smoking influences the composition and amount of saliva which may foster the occurrence of yeast [29]. Krishnan et al. evaluated the occurrence of Candida spp. in saliva samples collected from smokers and non-smokers with periodontitis and from the control group (non-smokers without periodontitis). Candida spp. was observed in $76.6 \%$ of smokers with periodontitis, $73.3 \%$ of non-smokers with periodontitis and $36.6 \%$ of control group members. Statistical differences were noticed between smokers with periodontitis and the control group. Candida albicans was the species most often isolated from smokers' saliva samples (50\%), then $C$. krusei $(10 \%)$ and $C$. tropicalis (10\%). To less often observed species belonged $C$. glabrata (3.3\%) and C. parapsilosis (3.3\%) [30]. The analysis showed that the presence of Candida spp. (33.6\%) was reported in people who declared smoking regular cigarettes or electronic cigarettes. C. tropicalis was 
observed most often. This observation may be a starting point for further research on the dependency between the presence of individual Candida spp. species and the type of smoked cigarettes. According to Wu et al. the substances in cigarettes facilitate the development of many microorganisms including S. mutans, S. gordonii, Actinomyces and C. albicans. Moreover, smoking influences the changes in saliva which fosters the creation of an environment favourable for the development of dental caries and potential pathology of the oral cavity [31].

\section{Conclusions}

Candida yeasts can show increased presence in the microbiota of the oral cavity in people of any ages. They can occur as individual species (C. albicans or $C$. tropicalis or $C$. glabrata) and can coexist with other species. Additionally, chronic diseases, predisposition to oral infections and smoking all significantly influence the composition of microflora and the appearance of fungi (quantitatively and with multidues of other species). In the future, if the immune system becomes supressed, this may result in various pathological states which can vary from mild to severe fungal infections, e.g. invasive fungal disease.

\section{References:}

1. Trzmiel D, Lis-Święty A, Bergler-Czop B. [Clinical characteristics of dermatomycoses and mycotic infections of skin appendages in the practice of a general physician - a still live issue]. Medycyna Ogólna i Nauki o Zdrowiu. 2011; 17(4): 212-217 (in Polish).

2. Petkowicz B, Skiba-Tatarska M, Wysokińska-Miszczuk J. [Oral candidiasis]. Gerontologia Polska. 2006; 14(4): 160-164 (in Polish).

3. Staniszewska M, Bondaryk M, Kowalska M, Magda U, Łuka M, Ochal Z, et al. [Pathogenesis and treatment of fungal infections by Candida Spp]. Post Mikrobiol. 2014; 53(3): 229-240 (in Polish).

4. Mayer FL, Wilson D, Hube B. Candida albicans pathogenicity mechanisms. Virulence. 2013; 4(2):119-128.

5. Dawgul M, Barańska-Rybak W, Bielińska S, Nowicki R, Kamysz W. [The influence of antimicrobial peptides on Candida biofilm]. Alergia Astma Immunologia. 2010; 15(4): 220-225 (in Polish).

6. Mnichowska-Polanowska M, Giedrys-Kalemba S, Kaczała M. [Candida biofim characteristics]. Mikologia lekarska. 2009; 16(3): 159-164 (in Polish).

7. Arendrup Maiken C. Epidemiology of invasive candidiasis. Current Opinion in Critical Care. 2010; 16: 445452. https://doi.org/10.1097/MCC.0b013e32833e84d2

8. Sikora M, Gołaś M, Piskorska K, Swoboda-Kopeć E. [Virulence factors of Candida species important in the pathogenesis of infections in patients with total parenteral nutrition]. Post Mikrobiol. 2015; 54(3): 224-234 (in Polish).

9. Dąbkowska M, Sikora M, Swoboda-Kopeć E, Netsvyetayeva I, Jarzynka S, Pertkiewicz M, et al. Mycological analysis of clinical materials of patients receiving total parenteral nutrition]. Med Doś. Mikrobiol. 2010; 62(2): 163-170 (in Polish).

10. Staniszewska M, Bondaryk M, Piłat J, Siennicka K, Magda U, Kurzątkowski W. [Virulence factors in Candida albicans]. Przegl Epidemiol. 2012; 66: 629-633 (in Polish).

11. Lewińska-Chełstowska M, Banach J. [Oral candidiasis in renal transplant patients medicated with cyclosporin A and tacrolimus]. Dent Med Probl. 2004; 41(4): 671-674 (in Polish).

12. Kurnatowska A, Kurnatowski P. [Medical mycology]. Wrocław: Edra Urban \& Partner; 2018 (in Polish).

13. Krutkiewicz A. [Factors of Candida albicans pathogenicity]. Mikologia lekarska. 2010; 17(2): $134-137$ (in Polish).

14. Karkowska-Kuleta J, Rapala-Kozik M, Kozik A. Fungi pathogenic to humans: molecular bases of virulence of Candida albicans, Cryptococcus neoformans and Aspergillus fumigatus. Acta Biochim Pol. 2009; 56(2): 211224.

15. Kędzia A, Hołderna-Kędzia E. [The susceptibility of yeastlike fungi to Aromatol]. Pos Fitoter. 2016; 17(3): 167-171 (in Polish).

16. Jarzynka S, Swoboda-Kopeć E, Dąbkowska M, Augustynowicz-Kopeć E. [Phenotypic and genotypic characteristic of Candida spp. strains isolated from patients with suspected catheter-related bloodstrem fungal infections]. Postępy Nauk Medycznych. 2015; 4b: 16-22 (in Polish).

17. Dhaliwal JS, Murang ZR, Ramasamy DTR, Munikumar Ramasamy Venkatasalu MR. Oral microbiological evidence among palliative patients: an integrated systematic review. Indian J Palliat Care. 2020; 26(1): 110115. https://doi.org/10.4103/IJPC.IJPC_178_19

18. Singh A, Verma R, Murari A, Agrawal A. Oral candidiasis: an overview. J Oral Maxillofac Pathol. 2014; 18: S815. https://doi.org/10.4103/0973-029X.141325 
19. Noble SM, Gianetti BA, Witchley JN. Candida albicans cell type switches and functional plasticity in the mammalian host. Nat Rev Microbiol. 2017; 15(2): 96-108. https://doi.org/10.1038/nrmicro.2016.157

20. Jayachandran AL, Katragadda R, Thyagarajan R, Vajravelu L, Manikesi S, Kaliappan S, et al. Oral candidiasis among cancer patients attending a tertiary care hospital in chennai, South India: an evaluation of clinicomycological association and antifungal susceptibility pattern. Can J Infect Dis Med Microbiol. 2016; 2016: 8758461. https://doi.org/10.1155/2016/8758461

21. Teoh F, Pavelka N. How chemotherapy increases the risk of systemic candidiasis in cancer patients: current paradigm and future directions. Pathogens. 2016; 5(1): 6. https://doi.org/10.3390/pathogens5010006

22. Delaney C, O’Donnell LE, Kean R, Leighann Sherry L, Brown JL, Calvert G, et al. Interkingdom interactions on the denture surface: implications for oral hygiene. Biofilm. 2019; 1: 100002. https://doi.org/10.1016/j.bioflm.2019.100002

23. Słotwińska S, Pierzynowska E, Foik T. [Occurence of Candida species in the oral cavity of patients with gingivitis and periodontitis]. Nowa Stomatologia. 2000; 3: 51-54 (in Polish).

24. Dudko A, Kurnatowska A. [Occurence of fungi in oral cavity of patients with periodontitis]. Wiadomości Parazytologiczne. 2007; 53(4): 295-300 (in Polish).

25. Gajdzik-Plutecka D, Wacińska-Drabińska M, Olczak-Kowalczyk D. [Oral candidiasis - pathogenesis, clinical picture]. Nowa Stomatologia. 2009; 14(1-2): 17-20 (in Polish).

26. Krawiecka E, Jankowski M, Kryś J, Radecka M, Smoczyńska-Marczak M, Piotrowska I, et al. [Evaluation of the oral cavity state and Candida occurence in generalny health Polish and foreign dental students]. Dental Forum. 2013; 41(1): 21-25 (in Polish).

27. Krawczyk D. [Permanent tooth caries and the bacterial count in saliva and dental plaque]. Dent Med Probl. 2009; 46(2): 202-207 (in Polish).

28. Jaworska-Zaremba M, Mierzwińska-Nastalska E, Swoboda-Kopeć E. [Laboratory evaluation of fungi sensitivity, isolated in denture stomatitis, to natural agent - tea tree oil]. Nowa Stomatologia. 2012: 4: 165169 (in Polish).

29. Soysa NS, Ellepola AN. The impact of cigarrette/tabaco smoking on oral candidosis: an overview. Oral Diseases. 2005; 11: 268-273. https://doi.org/10.1111/j.1601-0825.2005.01115.x

30. Krishnan SG, Naik D, Uppoor A, Nayak S, Baliga S, Maddi A. Candidal carriage in saliva and subgingival plaque among smokers and non-smokers with chronic periodontitis - a cross-sectional study. Peer J. 2020; 8: e8441. https://doi.org/10.7717/peerj.8441

31. Wu J, Li M, Huang R. The effect of smoking on caries-related microorganisms. Tob Induc Dis. $2019 ; 17: 32$. https://doi.org/10.18332/tid/105913 